\title{
Migrants' and refugees' health status and healthcare in Europe: a scoping literature review
}

\author{
Adele Lebano ${ }^{1,2^{*}} \mathbb{D}$, Sarah Hamed ${ }^{1}$, Hannah Bradby ${ }^{1}$, Alejandro Gil-Salmerón ${ }^{3}$, Estrella Durá-Ferrandis ${ }^{3}$, \\ Jorge Garcés-Ferrer ${ }^{3}$, Fabienne Azzedine ${ }^{4}$, Elena Riza ${ }^{5}$, Pania Karnaki ${ }^{6}$, Dina Zota ${ }^{6}$ and Athena Linos ${ }^{6}$
}

\begin{abstract}
Background: There is increasing attention paid to the arrival of migrants from outwith the EU region to the European countries. Healthcare that is universally and equably accessible needs to be provided for these migrants throughout the range of national contexts and in response to complex and evolving individual needs. It is important to look at the evidence available on provision and access to healthcare for migrants to identify barriers to accessing healthcare and better plan necessary changes.

Methods: This review scoped 77 papers from nine European countries (Austria, Cyprus, France, Germany, Greece, Italy, Malta, Spain, and Sweden) in English and in country-specific languages in order to provide an overview of migrants' access to healthcare. The review aims at identifying what is known about access to healthcare as well as healthcare use of migrants and refugees in the EU member states. The evidence included documents from 2011 onwards.

Results: The literature reviewed confirms that despite the aspiration to ensure equality of access to healthcare, there is evidence of persistent inequalities between migrants and non-migrants in access to healthcare services. The evidence shows unmet healthcare needs, especially when it comes to mental and dental health as well as the existence of legal barriers in accessing healthcare. Language and communication barriers, overuse of emergency services and underuse of primary healthcare services as well as discrimination are described.

Conclusions: The European situation concerning migrants' and refugees' health status and access to healthcare is heterogeneous and it is difficult to compare and draw any firm conclusions due to the scant evidence. Different diseases are prioritised by different countries, although these priorities do not always correspond to the expressed needs or priorities of the migrants. Mental healthcare, preventive care (immunization) and long-term care in the presence of a growing migrant older population are identified as priorities that deserve greater attention. There is a need to improve the existing data on migrants' health status, needs and access to healthcare to be able to tailor care to the needs of migrants. To conduct research that highlights migrants' own views on their health and barriers to access to healthcare is key.
\end{abstract}

Keywords: Migration, Healthcare, Refugees, Asylum seekers, Services, Policy, Vulnerable migrants, Social care, Equality, Discrimination

\footnotetext{
* Correspondence: adele.lebano@soc.uu.se; adele.lebano@ed.ac.uk

'Uppsala University, Department of Sociology, English Park Campus - Centre

for the humanities, Thunbergsvägen. 3H, Uppsala, Sweden

${ }^{2}$ University of Edinburgh, School of Social and Political Science, Chrystal

Macmillan Building15a, George Square, Edinburgh EH8 9LD, UK

Full list of author information is available at the end of the article
}

(c) The Author(s). 2020 Open Access This article is licensed under a Creative Commons Attribution 4.0 International License, which permits use, sharing, adaptation, distribution and reproduction in any medium or format, as long as you give appropriate credit to the original author(s) and the source, provide a link to the Creative Commons licence, and indicate if changes were made. The images or other third party material in this article are included in the article's Creative Commons licence, unless indicated otherwise in a credit line to the material. If material is not included in the article's Creative Commons licence and your intended use is not permitted by statutory regulation or exceeds the permitted use, you will need to obtain permission directly from the copyright holder. To view a copy of this licence, visit http://creativecommons.org/licenses/by/4.0/. The Creative Commons Public Domain Dedication waiver (http://creativecommons.org/publicdomain/zero/1.0/) applies to the data made available in this article, unless otherwise stated in a credit line to the data. 


\section{Background}

The European Union (EU) comprises a heterogeneous population that includes migrants coming from nonEuropean countries. A migrant is here intended, according to the UN definition, as "someone who changes his or her country of usual residence, irrespective of the reason for migration or legal status" [1]. According to Eurostat data, on 1st January 2014, there were 33.5 million people born outside the EU, which represents $6.6 \%$ of the total EU population. Of these, 19.6 million were still citizens of countries outside the EU, while 14.3 million were citizens of one EU country, but living in another one [2]. In 2015 the EU received more than 1.2 million first time asylum applications. Although this is a much smaller number compared to migration within the global South, it is still more than double the number received in the previous year, which has raised both interest and concern around the impact of migrants and refugees on European healthcare systems. The number of new asylum applications has decreased since 2015 to fewer than 600,000 in 2018, yet the concerns have not been eased. Migrants from different European and non-European countries imply new demands on national public services, not least healthcare. Such demands are going to be the rule, as the fast altering political situations in various countries around the world, the ongoing global financial crisis, together with the growing implications of climate change makes it likely that a new migration wave may happen even when restrictions are put in place by EU member states.

All the EU member states have formally recognised the right for every person to the highest attainable standard of physical and mental health. However, due to the variations in socioeconomic level in the various European Union states, the different healthcare systems as well as the variation in the number of migrants arriving, achieving data to describe the situation, let alone achieving this highest attainable standard across EU countries is challenging. Recording the citizenship of legally recognised migrants captures part of the population of immigrants, but does not include naturalised migrants. Numbers of irregular or undocumented migrants are difficult to ascertain and definitions differ by member state within the European Union and across countries, making comparisons challenging. How healthcare can and should be provided for national populations with high levels of immigration is a crucial issue, but one that is difficult to address even if good quality data were available. Some attempts have been made to bring attention to these data gaps, including a report [3] providing an overview of migrants' health in Europe, documenting knowledge gaps and calling for action, and a study [4], which looked at various issues in regards to migrants' health needs globally, showing the discrepancy that exists between emphasis on health rights and equity on the one hand and the actual provision of equal healthcare on the other. Considering the importance of providing optimal healthcare for migrants, it is necessary to gain an overview of migrants' access to healthcare in various European countries. This review provides an overarching picture of the current state of knowledge regarding migrants' health status, access to and use of healthcare in Europe. This article is a scoping review that is part of the MigHealthCare project and includes Austria, Cyprus, France, Germany, Greece, Italy, Malta, Spain, Sweden - the European countries that make up the MigHealthCare consortium. ${ }^{1}$

The research questions guiding the review of the literature are as follows:

- What is known about the physical and mental health status of migrants and refugees in the EU member states? This topic was included in the literature review because it provides insight into the access to healthcare question.

- What is known about healthcare access and use of migrants and refugees in the EU member states?

\section{Methods}

\section{Sources of evidence}

Due to the scattered and fragmented nature of the literature, conducting a systematic review was not possible. Further, the topic cuts across many disciplines and methodologies and is relatively underexplored. The aim of this review was to map existing research on the topic, both qualitative and quantitative, scholarly articles and grey literature. The importance of mapping the existing research is to gain an overall comprehensive insight into what has been conducted as well as gaps in research. Given the nature of the task, and the state of the research, a scoping review is appropriate as it aims to map rather than the assess the quality of the studies that are included [5].

A scoping review of the academic and grey literature in different European languages (English, French, German, Greek, Italian, Maltese Spanish, and Swedish) was undertaken by the consortium partners.

The search was conducted according to the following main criteria specifying time-frame, databases and search terms:

- Time frame: 2011 to 2017 (the rationale for this is that 2011 saw the beginning of the Syrian and Libyan revolutions accompanied by an increase in the flow of migrants towards the EU 28 countries)

\footnotetext{
${ }^{1^{1}}$ The MigHealthCare consortium includes 14 partners from 10 European countries among which universities, Non-Governmental Organisations (NGOS) and national authorities with a composite range of expertise on health, migration, equality and integration issues.
} 
- Databases: PubMed, ScienceDirect, Scopus, PsycInfo, Social Services Abstracts (also in ProQuest), Cochrane library, CABI. Eurostat, OECD, Eurofound, CORDIS and any other databases that are available in the different languages included in the search.

- The search terms: Topic: (migrant* or migration or immigrant" or foreign" or (minority near groups) or refuge* or asylum) AND TOPIC: service* or access" or planning or delivery) AND TOPIC: (health or medical), dental care, obstetrics/gynaecology, mental health, social care

\section{Selection process}

The evidence collected included:

- Academic articles and literature reviews (each country in its own language)

- Grey literature (think tanks, non-governmental organisation and government reports)

Articles were included in the review if they were relevant to the research questions and were in the following languages: English, French, German, Greek, Italian, Maltese Spanish, and Swedish.

\section{Data extraction and coding}

Seventy seven papers were included in this review (see Table 1 in the Annex). The initial screening of the sources was done by the national teams. Each team used a common template to write a review in English of each source included. Uppsala University in collaboration with the national teams conducted the analysis. The sources included were coded thematically and classified according to major themes and subthemes:

- Migrants' health status. This theme is divided in - communicable and non-communicable diseases

- mental health in adult refugees and migrants

- children's health status

- Social determinants of health. This theme is included for the link between socio-economic condition and health status.

- Access to healthcare. The theme is divided in

$\circ$ access to maternal health services

- communication and information issues

- Use of healthcare service

- Challenge to healthcare provision in transfer countries. This is a theme in its own right because transfer countries are reported to face common problems but to a higher degree.

This final classification was discussed and validated by the MigHealthCare consortium members.

\section{Results}

Seventy seven sources are analysed in this section and organised according to the above described thematic classification. Figure 1 describes the selection process.

\section{Migrants' health status}

The literature reviewed on health status was organized into the following focus areas: communicable and noncommunicable diseases; mental health in adult refugees and migrants; children's health status.

\section{Communicable and non-communicable diseases}

Migrants' health status is influenced by the hardships of the migration process which negatively affects the physical health status of migrants. This was shown in a French study [6] that demonstrated how migrants' health status tended to deteriorate with duration of stay which may be due to discrimination; poor employment conditions; differences in access and use of healthcare services. The study suggested that "migrant health deficit effect" (in comparison with natives), is less pronounced for second-generation migrants (people born in France to foreign-born parents). Similarly, an Austrian study showed that the population of migrant origins suffers to a greater extent than the resident population from heart disease, allergies, digestive and urogenital and dermatological problems and emphasizes the link between migrants' health conditions and the stressful situations they face in both the workplace and the community at large [69]. Another study comparing European countries also suggested that migrants are more vulnerable to communicable diseases, occupational diseases, poor mental health, injuries, diabetes mellitus, and maternal and child health problems [8]. Two studies focusing on vulnerable migrants living in open centres in Malta [70] and in detention centres in Greece and Malta [10] showed that the prevalence of HIV, tuberculosis and non-communicable diseases (e.g. hypertension and diabetes) is higher among the non-European migrant population. However, it is difficult to compare across countries, as studies focused on specific health conditions and ethnic groups. For example, of the studies included in this review, four focused on specific conditions: ophthalmic disease [11]; HIV [13]; tuberculosis [14], skin diseases gynaecological concerns and other unattended health-related problems [15-17, 71, 72].

To conclude, data on migrants' physical health status are insufficient on the basis of the literature reviewed. Some migrants might be at particular risk of non-communicable diseases arising from obesity and insufficient physical activity due to patterns of disease in countries of origin, disadvantageous living conditions, precarious employment and trauma. 


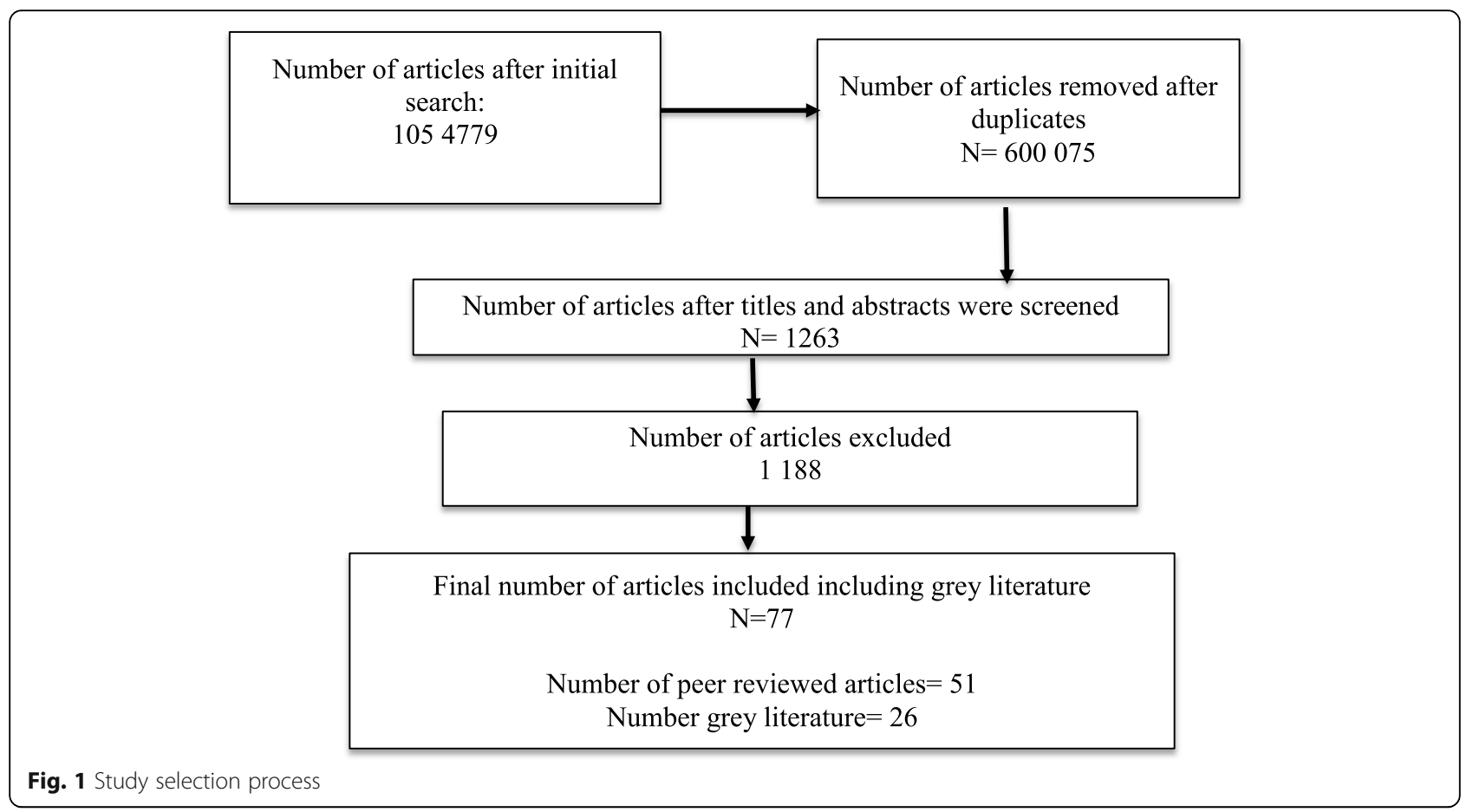

\section{Mental health in adult refugees and migrants}

The articles that were reviewed show that refugees and migrants tend to have higher prevalence of mental distress compared to non-refugees in Europe. Ten of the papers that were reviewed focus on the mental health of migrants, mostly refugees. A German study found an association between depressive symptoms and migration status in the older migrant populations [73]. A more recent study described the mental health condition of asylum seekers who passed through Médecins sans Frontières clinics in Sicily between October 2014 and December 2015 and, when invited, presented themselves for mental health screening [74]. Of the 385 who were screened, most were young men who had left their home countries in West Africa more than a year prior to arrival. The most common mental health conditions were post-traumatic stress disorder (31\%) and depression (20\%). Most of the potentially traumatic events were reported to have been experienced in the home country (60\%) and during the journey (89\%), but the trauma of being a refugee was also reported, with activity deprivation, worries about people who were left behind, loneliness and fears of being sent back [74].

Another study found a connection between psychosis and a background as an irregular migrant [18]. Similarly, an Italian report underlined that although empirical data and scientific research on the topic of migrants' mental health is still rare, practitioners and sector operators have experienced the increase in requests for psychiatric care from migrants who have lived traumatic situations, social marginalization, lack of social support and are therefore at higher risk of post-traumatic stress disorders [19]. The same Italian study highlighted how structural barriers impede the effective transfer of patients to further care facilities. High levels of stress in detention centres are linked to the reporting of non-specific physical symptoms [70] as a form of somatization of psychosocial stress suggesting underlying mental disorders.

Not only previous traumatic experience influences mental health but also duration of stay, as suggested by a study conducted by the Jesuit Refugee Service (JRS) in 2010. This study stated that $80 \%$ of Asylum Seekers interviewed reported a deterioration in their mental health since their arrival in the detention centre. From a population of around 500 detainees, 74 individuals required in-patient psychiatric care [20]. A project conducted in Malta by Aditus and a UN agency underlined mental health problems affecting a large proportion of the refugee community, including post-traumatic stress disorder, depression, anxiety, psychosis, paranoia and self-harm; feelings of isolation and loneliness were also mentioned by refugees as major concerns to service providers [41] Reported symptoms such as stress, anxiety disorders, panic attacks, and other psychiatric problems were said to be the most common symptoms in some camps more than in others [18].

There seems to be a growing interest in the mental health condition of migrants, even though the studies that look at this issue seem to focus mostly on refugees- for whom there is a presumption that mental health problems arise from uncertain migration status. 


\section{Children's health status}

Five studies focused specifically on children's health status. A French study showed that children born in a hepatitis A endemic area have a significantly higher prevalence of hepatitis A seropositivity compared to children born in France, possibly as a result of exposure during overseas trips to visit family or of family members visiting from the endemic areas, implying an urgent need to vaccinate children [75]. Another study in France underlined the lack of clinical practice recommendations for the care of unaccompanied refugee minors as causing significant disparities depending on the department or region to which the young person arrived. The most frequently diagnosed serious conditions were digestive parasites, schistosomiasis, filariasis, hepatitis B and iron deficiency and the failures of care implied the need for standard care to be defined [22].

Vaccination status and dental issues as well as Latent Tubercolosis Infection (LTBI), anaemia, low serum ferritin, eosinophilia, and protective antibodies among migrants were discussed in a Greek study of child migrants [23]. Reports of hypothermia after arrival by sea and mental health challenges associated with the experience of violence, separation from family, insecurity, inadequate housing, trafficking, and sexual exploitation were also recorded [24].

Oral health was also discussed in a study of 12-year-old migrants in Austria that showed the prevalence of caries among children born to migrants was $42 \%$ higher compared with children with no migrant background. Children with a migrant background were more affected by gingivitis (gum inflammation) and less likely to seek orthodontic treatment or counselling compared to other 12-year-olds. The report underlined how better use of group prophylaxis and individual healthcare prevention would be a means of reducing unequal distribution of health risk [25].

Generally, our review found that references describing child migrants' health status are limited, country specific and focus on specific illnesses, making it difficult to draw comparisons and commonalities across countries or to determine the health status of children with migrant background within each country.

\section{Social determinants of health}

In the WHO definition, the social determinants of health "are the condition in which people are born, grow live, work and age" and bear the major responsibility for differences in health status. As it affects health status, we decided to include the literature looking at social determinants of health in this review. The majority of studies [69] in this review looking at social determinants of health were conducted in France [6, 26, 27, 29-32] and three in Malta [21, $28,70]$. According to a systematic literature review, the link between socio demographic conditions and health is stronger for migrants than for the native population [6]. In France, studies reported on the increased health risks for homeless migrants [26], including chronic diseases. A hospital polyclinic in Paris used overwhelmingly by migrants was surveyed and, although their average duration of stay in the country was 12 years, about half of the sample were undocumented and a quarter had no health insurance. Vulnerable migrants in France (including minors, women, and people with disability) were found to have poor self-rated health and poor living conditions as well as being exposed to violence. A study focused on the health effects of violence [7], showed that $84 \%$ of 128 women migrants consulting a 'Médecins du Monde' clinic in Paris had faced violence, whether verbal, physical or sexual.

Prevalence of having experienced violence and insecurity was higher for people living in public emergency accommodation and those who were homeless than for those living in camps or in someone else's accommodation according to people's declaration [29]. Migrants and especially women migrants from sub-Saharan Africa in France in 2012-2013 faced precarious administrative and social conditions, associated with poor health outcomes [30]. The same study showed that compared to women, men's diagnosis occurred after a longer delay following arrival in France and occurred more frequently during an active phase of the disease. An ethnographic study from 2015 showed that the availability of accommodation for migrants was positively linked to migrant access to healthcare [30] .

Discrimination against migrants' access to employment or healthcare was shown to be a pressing issue in another French study. Discrimination due to a migrant's country of origin is shown to have consequences for health status not just for immigrants who are newly arrived, but throughout their life course [32].

In a study from Malta the social and economic environment of migrants, the harsh living conditions in open centres and detention homes, have been shown to lead to negative health outcomes [70]. Other factors such as limited access to paid work was raised as a concern in the literature that was reviewed. Reference was made to particular sub-Saharan African asylum seekers who seemed especially vulnerable to exploitation and abuse [28]. Over 2000 immigrants in Malta, living in open centres were assessed between August 2010 to June 2011 and the following factors were found to be detrimental to health outcomes: the environment in detention homes including exposure to cold, a lack of space and overcrowding, a lack of activity, poor diet and high levels of stress; together with a lack of systematic and/or preventive medical care and a lack of treatment for infections and diseases. Furthermore, the report emphasizes how the detention context poses additional significant challenges for asylum seekers and migrants with chronic medical conditions, disabilities or mental health problems.

Although these results emphasize the need for stable accommodation available regardless of the migrant's 
legal status as a key means of promoting increased health equality for migrants, the studies only reflect findings from France and to some extent Malta, making it difficult to generalise.

\section{Access to healthcare}

Evidence of migrants' access to healthcare is scant. Access to healthcare for refugees, asylum seekers and migrants varies across European countries in terms of regulation and laws [33]. Even when legal accessibility is available, differences and inequalities still exist in accessing healthcare $[12,34,35,56]$.

Organisational and administrative issues were highlighted as barriers to access healthcare for migrants in studies from Italy and Greece [35]. A European report (2016) suggests that there is a lack of institutionalized procedures for taking care of unaccompanied minors leading to frequent breaks in the continuity of care [18].

Undocumented migrants' access to healthcare is especially problematic [37]. Two qualitative studies [18, 40] and a narrative review [36] focused on undocumented adult migrants and refugees in different European countries, health needs and access to health services and concluded that healthcare services are underused by undocumented migrants, since these migrants tend to be unaware of their entitlement, and when they receive care, it tends to be inadequate.

Marques (2012) reviewed countries in regard to access to healthcare for undocumented migrants and refugees showing a multi-faceted picture. Even though access to healthcare may be granted by law, as in France, other barriers such as lack of knowledge, administrative requirements, language difficulties, and fear of being reported, as well as discriminatory practices and refusal of care are mentioned as obstacles to accessing care [42].

In the section below, we review communication and information issues and particular factors affecting access to healthcare for migrant women.

\section{Access to maternal health services}

Evidence on maternal healthcare focused mainly on specific issues such as female genital circumcision (FGC) [76], the delayed use of maternal health services by certain groups of migrants [48], and inequalities in pregnancy and childbirth [49]. FGC was investigated together with prenatal care in refugee women from Syria, Somalia, Libya, Eritrea, Ethiopia, and the Ivory Coast in Malta [76]. Obstacles identified in access to healthcare included language barriers, not only within the healthcare setting, but also in using transport to reach healthcare services [76].

Insufficient interpreters and lack of cultural mediators, communication and information barriers were mentioned in two studies $[49,76]$. These obstacles led to women missing important appointments, required medical tests remaining incomplete and women feeling uncomfortable [76]. Existing inequalities in childbirth outcomes for migrant women in Europe were evident, and underlined the lack of evidence for planning improved care and access to care [49].

\section{Communication and information issues}

Evidence showed a heterogeneous situation in European countries concerning health literacy between migrants and non-migrants [51]. A number of studies highlighted underaddressed cultural and communication issues described below [44-46, 77] between migrants and healthcare providers leading to poor health service provision for migrants, governance problems and incoherent distribution of power and responsibility for the provision of healthcare between different actors as reported by an Italian study [47].

A German comparative study looked at migrants from several European countries and demonstrated that migrants make more use of first-aid stations; show predictable communication and understanding difficulties and have different views about health and illness compared to 'nonmigrants'; the results were suggestive of barriers to the use of regular healthcare services among migrants [55].

Two studies showed that lack of information regarding available care options and language barriers were among the factors contributing to migrants' health vulnerability $[38,39]$. A lack of knowledge concerning specific diseases such as HIV and AIDS and other sexually transmitted diseases was reported by a quantitative study of 600 migrants from "third countries" in Cyprus [39]. Factors such as "high cost, lacking awareness of the healthcare system, culturally insensitive services, different perceptions of illness and stigma, as well as limited language skills" were highlighted in a Finnish study among various groups of migrants (Russians, Somalis and Kurds) and were shown to contribute to an increasing perception of unmet needs [52].

A multi-method study in Austria focusing on migrants from Turkey and former Yugoslavia, compared various groups of migrants in terms of their previous experiences with healthcare, showed that different groups of migrants had the same level of health literacy as the general population [50]. On the other hand, 455 adult refugees speaking Arabic, Dari, Somali or English were surveyed in Sweden showing that the majority of these refugees had inadequate or limited health literacy, both functional and comprehensive. The study recommended that levels of health literacy should be taken into consideration in activities addressing migrants [53]. Another study in Spain also recommended action research as a way to tackle poor health among migrants [43].

Concerning the perceptions of migrants' own health and unmet health needs, an Italian study among 
migrants in Spain and Italy shows that perceptions of unmet healthcare needs have increased from 2007 to 2012 among the migrant population in Italy [51]. By contrast, in Spain 2012, the native population's perception of unmet needs also increased.

\section{Migrants' healthcare use}

Under this category we included studies dealing specifically with migrants' patterns of use of healthcare services. Most of the studies of healthcare use tend to homogenise migrants and compare/oppose them to non-migrants who are also homogenised- e.g. [54, 55, 57]. These studies often highlighted the increased use of emergency room (ER) or acute care provision by migrants compared to non-migrants and the increased likelihood of visiting ER during unsocial hours as well as increased use of obstetrical and gynaecological services among migrant women $[54,55,57]$. At the same time, migrants, especially certain vulnerable groups such as first generation migrant women, are shown to use preventive screening and preventative services less than non-migrants $[8,9]$.

Similarly, a Spanish study with healthcare providers showed a perception that emergency service is the main access route for migrants and reported failures in the continuity of care for immigrant patients. Variations existed, however, among migrants depending on both their country of origin and the level of social integration [60].

A study of how migrants in Greece made use of the healthcare available to them, showed that compared with non-migrant patients, hospitalization rate was lower for chronic conditions but higher for accident-related diagnoses, treatments for infectious disease, and medical conditions related to depression or alcohol use (including: $\mathrm{TB}$, gastritis/gastroenteritis, hepatitis, pneumonia, alcohol-related conditions, poisoning, and allergy) [57].

A study of the utilization of hospital services by the patient's country of origin in Aragona, Spain showed that foreigners tend to use the public hospital less than the native population. However, this observation is inconclusive since the variation in prevalence of different diseases in immigrants' countries of origin meant that the reason for using hospitals services varied by country of birth of the immigrants [58].

A review of mainly survey-based evidence of healthcare providers on the use of healthcare services among migrants showed no difference in the use of medical services by migrants compared to the native population. However, differences exist in the use of specialist care where migrants use of this type of care less [59].

A study in Vienna investigated the reasons for a reduced use of professional healthcare services even when needed, focusing on older migrants from Turkey, former Yugoslavia (Bosnia, Serbia), Poland and Iran [78]. The study evaluated the relevance of different reasons, from primary structural reasons (poverty, marginalization, discrimination), to a lack of knowledge about the care system, to insufficient 'transcultural competences' of the healthcare stuff. The solutions suggested aim at strengthening the "orientation towards the principles of openness, diversity and individuality" of the city of Vienna by recruiting people with migration experience/background as well as transcultural competencies.

Our review found that studies of healthcare use tend to offer simplified pictures of migrants versus locals, where both groups are taken as homogeneous. Such simplification makes it hard to reach a conclusion about the reasons behind the differences in healthcare use - whether socioeconomic circumstances, health status, or the system's lack of transparency and openness to diversity.

\section{Challenges to healthcare provision in transfer countries}

Understanding the challenges of providing care for new migrants has had a particular focus in countries such as Greece and Spain that are entry points for arrivals to Europe. The challenge that the refugee crisis posed to national health services in transfer countries was said to have received inadequate media coverage and to be too marginal in public debate [62].

The studies underline the needs of caregivers in transfer countries, in terms of psychological support; additional financial and human resources; training courses. They underline the limited availability of diagnostic equipment, mental care services and an integrated provision of care for new migrants that allows them to easily access different services, including translation and cultural mediation.

A Greek study on "caregivers working in contemporary refugee hotspots" found that caregivers suffer from psychological stresses and sleep disturbances as well as posttraumatic stress syndrome (7\% PTSD) [61]. Organisational issues faced by healthcare providers in these countries included problems of internal and external communication and coordination, cultural and language differences, inadequate funding, inadequate human resources to treat an overwhelming volume of refugees. Greece in particular was noted as one of the countries dealing with sheer numbers of refugees [63]. Other challenges faced by healthcare providers working in the front line in Greece included the limited availability of on-site diagnostic tests, electricity, and running water in camps [64].

A comparative study underlined the challenges faced by Greece, Italy and Slovenia. The study reported on insufficient training courses in transcultural competencies for health and social care professionals in Italy; staff shortages on the islands, lack of interpreters in emergency care departments, and a lack of suitable accommodation for vulnerable populations in Greece. In Slovenia the lack of funding to treat chronic noncommunicable diseases was emphasised. In all three 
countries poor coordination between participating organisations, for example with regards to supplying food and clothing to reception and accommodation centres, was blamed for the gap between demand and supply of goods and services [66].

An increase in migrants' requests for hospitalization and psychiatric care and deficiencies in the services that should provide mental care was reported by an Italian study [19]. In particular, the report referred to how traumatic and tragic experiences (including torture) and post- migration living difficulties contribute to posttraumatic stress disorder (PTSD). Although some special initiatives to address PTSD exist (the Protection System for Refugees and Asylum Seekers for example), the increased demand for support has proven difficult for the Italian State [19]. Serious deficiencies in the availability of cultural mediators and of expertise in migrant mental health, combined with the increased demand, placed a severe strain on the Italian provision of mental health services for migrants [65].

The availability and organisation of health assistance for migrants, refugees and asylum seekers through civil society organisations varies across European member states. The already mentioned qualitative report comparing Italy, Greece and Slovenia [64] shows that the services are centrally administered in Greece and Slovenia compared to Italy's regional organisation. Healthcare services for migrants, refugees and asylum seekers in Italy have been provided mainly by health professionals appointed by the ministry of health while in Greece, non-voluntary organisations (NGOs) have been playing a big part in providing healthcare. Slovenia has stateappointed health professionals undertaking the work alongside NGOs [66]. The creation of a Refugees' Health Unit in Greece offered the opportunity for healthcare providers working with a translator or cultural mediator [67]. In Spain, an Intercultural Mediation Programme for women mostly treated reproductive problems among Latin American women. The programme provided information, education and facilitated access to reproductive health services [68]. These last two examples suggest that integrated provision of care, whereby migrants can access a range of services, together with translation and cultural mediation as appropriate may represent a form of good practice.

According to the sources overviewed, transfer countries appear to face specific problems in the provision of healthcare for migrants and refugees, to a higher degree. Lack of money and of trained and stable human resources, organisational malfunctioning and poor coordination among the actors are all mentioned as factors hindering the provision of healthcare for migrants and refugees.

\section{Discussion}

Most of the articles which were reviewed focused on the health status of migrants and refugees, looking at communicable and non-communicable diseases, mental health and children's health status. Generally, the references describing health status of migrants are country specific and focused on specific illnesses, making it hard to draw comparisons across countries. Mental health is still relatively underexplored and studied mainly in relation to refugees- where the presumption that mental health problems arise from insecure migration status is confirmed. Sources addressing the social determinants of health emerged as another major focus of the current literature, especially in certain countries, and despite not being an initial focus of the research questions, were included for the link between socio-economic conditions and health status. Despite the aspiration to universal healthcare for all, inequalities persist in access and use to healthcare. Organisational and administrative issues, were highlighted including barriers, language and communication problems, overuse of emergency services and underuse of primary healthcare as well as structural and interpersonal dynamics biases towards migrants and refugees. Transfer countries are reported to face common problems but to a higher degree. Lack of funds and of trained and stable human resources; organisational malfunctioning and poor coordination among the different actors are all mentioned as factors hindering the provision of healthcare for migrants and refugees.

Although interest does exist in understanding health status and access to healthcare for migrants, the collection of data is fragmented and conducted in different settings and periods. This is an obstacle to monitoring and improving migrants' health status as there is a lack of reliable, standardized and shared procedures for routine collection of health data on migrants in European member states, which represents a significant impediment to ascertaining migrant health status across Europe. Practice around the demographic classification of populations varies with the disclosure of "ethnic" information forbidden in Sweden, for example, on the grounds of anti-discrimination legislation [79]. This makes it difficult to provide a detailed picture of the health status of particular ethnic groups, which may overlap substantially with migrant groups at specific moments in time.

The lack of common definitions (i.e., definitions of migrants, non-migrants, optimal care, etc.) and clearly defined goals hinders analysis and comparisons. In reporting on practice, it is often unclear whether a migrant is from outside or within the European Union, perhaps because care providers do not always know and, given the sensitivity of migration status, it may be difficult to establish. A top down approach of evaluation of 
healthcare needs of migrants is mostly used. However, there is hardly any investigation of how migrants' own, self-defined health needs can be met. Studies in different countries have different emphases making comparison difficult: some studies compare the health condition of migrants with the local population, with often contradictory results and context specific; other studies focus on health conditions of children pre-dating their migration (e.g. hepatitis, dental problems); while others consider the mental health unbalance between migrants and non-migrants. Reports mostly conducted in France underline the link between housing conditions and health.

Most articles on health status focused on communicable diseases. Less consideration is given to noncommunicable diseases, preventative care and the question of equity in health and in healthcare access. Recent studies have reported a higher use of emergency services by migrants and a higher likelihood of visiting ER during unsocial hours; together with the higher use of obstetrical and gynaecological services among migrant women compared with non-migrant women. These discrepancies may signal the presence of barriers to migrants' use of regular healthcare services. A few studies have investigated the accessibility of healthcare for migrants, testing intercultural policies aimed at helping healthcare providers meet the needs of migrants, while others have focussed on the conditions discouraging migrant from seeking care.

The body of scientific and grey literature reviewed here underlines that migrants' health status and the possibility of health equality is affected by multiple factors that influence migrants' ability to access healthcare. These include legal entitlement; knowledge of the health system in a new country; previous experience of healthcare; language and cultural barriers; health beliefs and attitudes; and the structure of the health system itself in the new country [33, 80]. The sources reviewed highlight similarities and differences among the European countries. Although the system of legal entitlement and the health system itself varies across European countries, there are problems in regard to knowledge of health system, language and cultural barriers and health beliefs and attitudes are common.

In the material that has been reviewed, there is clear evidence of the need to conduct research to highlight migrants' own views of their health and on barriers to access to healthcare.

\section{Limitations and strengths}

The literature review included nine countries across Europe. The fact that literature was gathered in the various languages of these countries contributes to the strength of this review by synthesising material that is often excluded from the evidence base. The partners were able to access literature, both peer-reviewed and grey literature, in their language, which increased the breadth of our search base and enabled the inclusion of a wider variety of reports from NGOs and official agencies, as well as getting beyond the literature available in English. On the other hand, the broadness of the topic and the scoping aim of the review could result in having missed some sources.

The literature reviewed was dominated by certain countries and by certain topics while others appeared less often, which may be due to the eyes of the reviewer as much as to the availability of data. The lack of a commonly held definition of what constitutes a migrant, an asylum seeker and a refugee and who counts as a vulnerable migrant, as well as the different sample sizes, analytical methods and the focus on specific ethnic groups, makes generalisation and drawing conclusions difficult. Measures and policies for migrants' healthcare were particularly hard to account for without better data on the effectiveness of the measures introduced so far, both the policies addressing patients and those addressing providers.

\section{Conclusion}

Evidence from different European countries shows that despite equitable aspirations inequalities between migrants and non-migrants in health and in access to healthcare services persist. Inequalities are the results of legal barriers in access to care for refugees and undocumented migrants, and are also due to the economic situation of migrants who may lack the means to pay for health services and / or may lack the language and cultural competency to navigate the healthcare systems and / or may be exposed to discrimination.

The European situation concerning migrants' health status and access to healthcare is heterogeneous and it is difficult to compare and draw any firm conclusions due to the scant evidence. Different diseases are prioritised by different countries, although these priorities do not always correspond to the expressed needs or priorities of the migrants. Mental healthcare, preventive care (immunization) and long-term care in the presence of a growing migrant older population are identified as priorities that deserve greater attention. There is a need to improve the existing data on migrants' health status, needs and access to healthcare to be able to provide optimal healthcare tailored to the needs of migrants. As migrants' own voices were not highly present in the reviewed data, there is need to conduct research to highlight migrants' own views on their health and barriers to access to healthcare. 


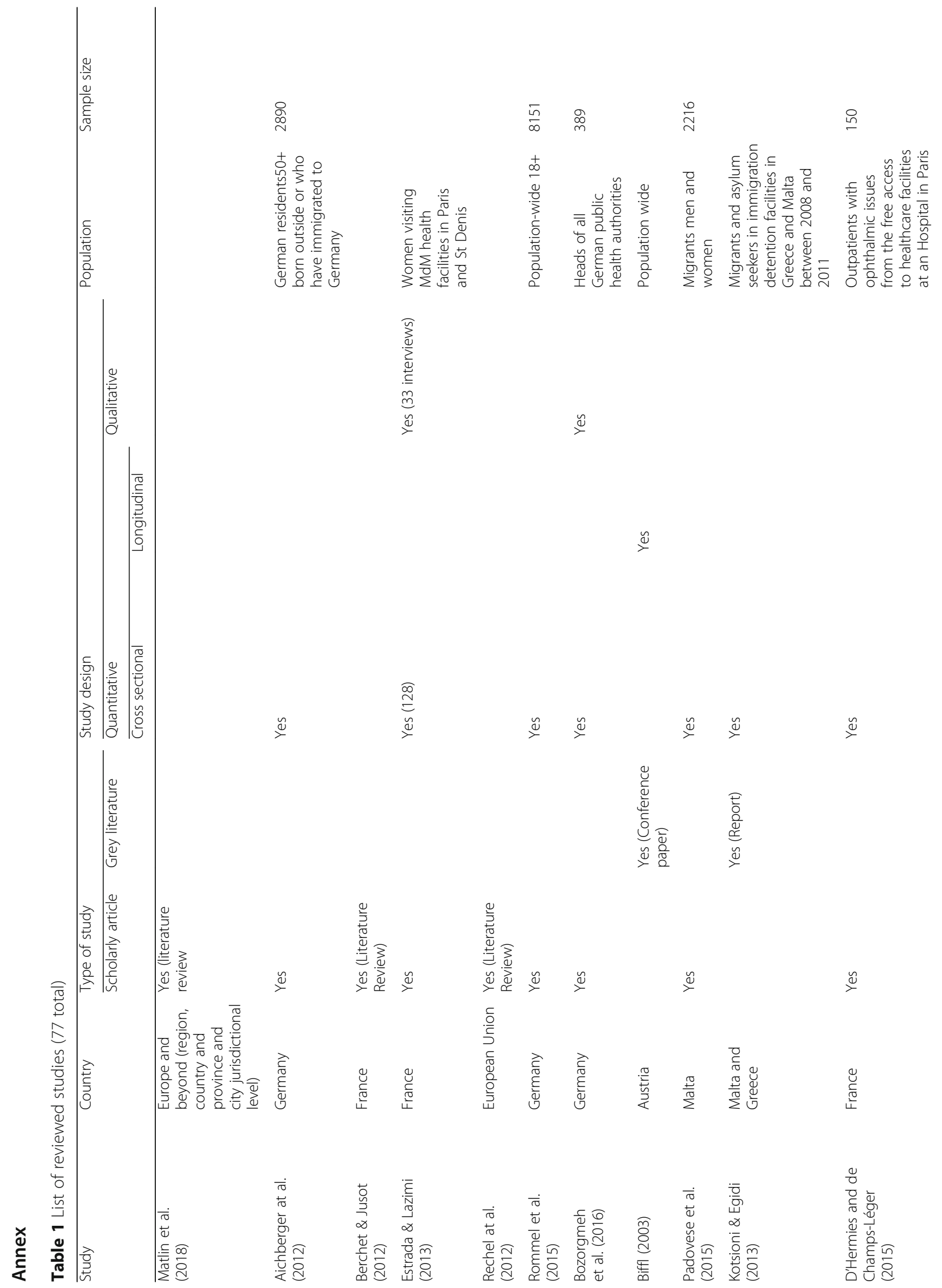




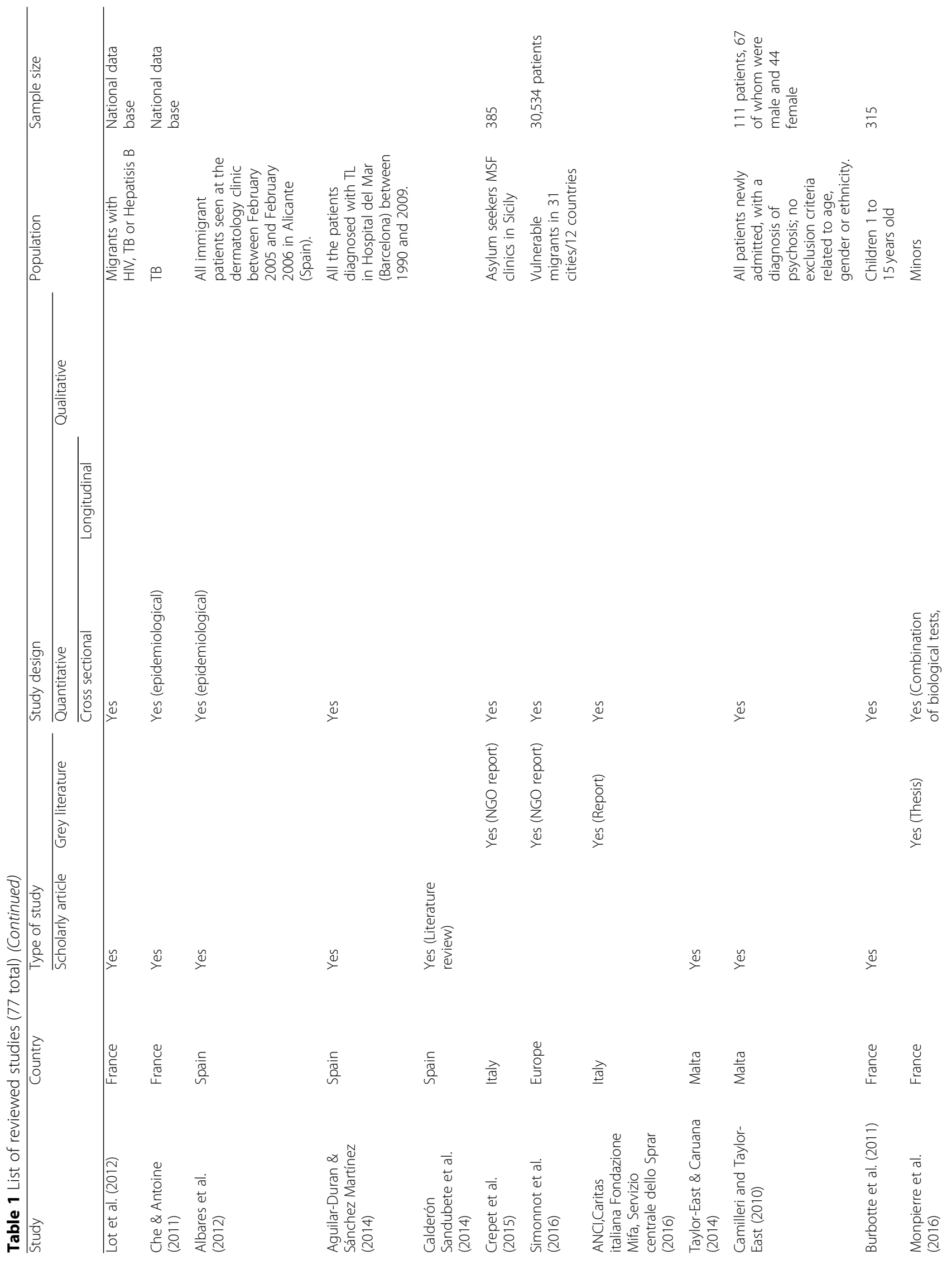




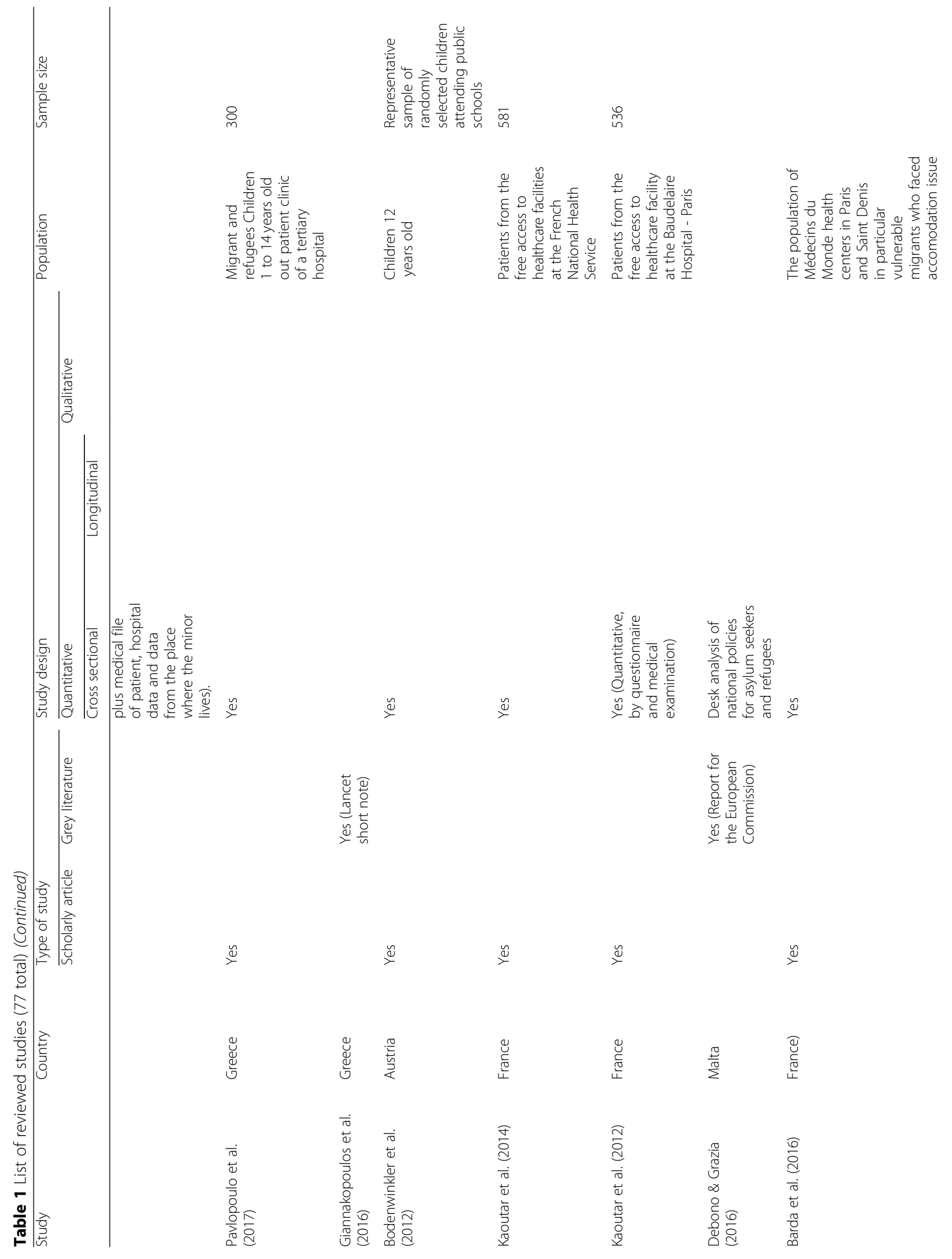




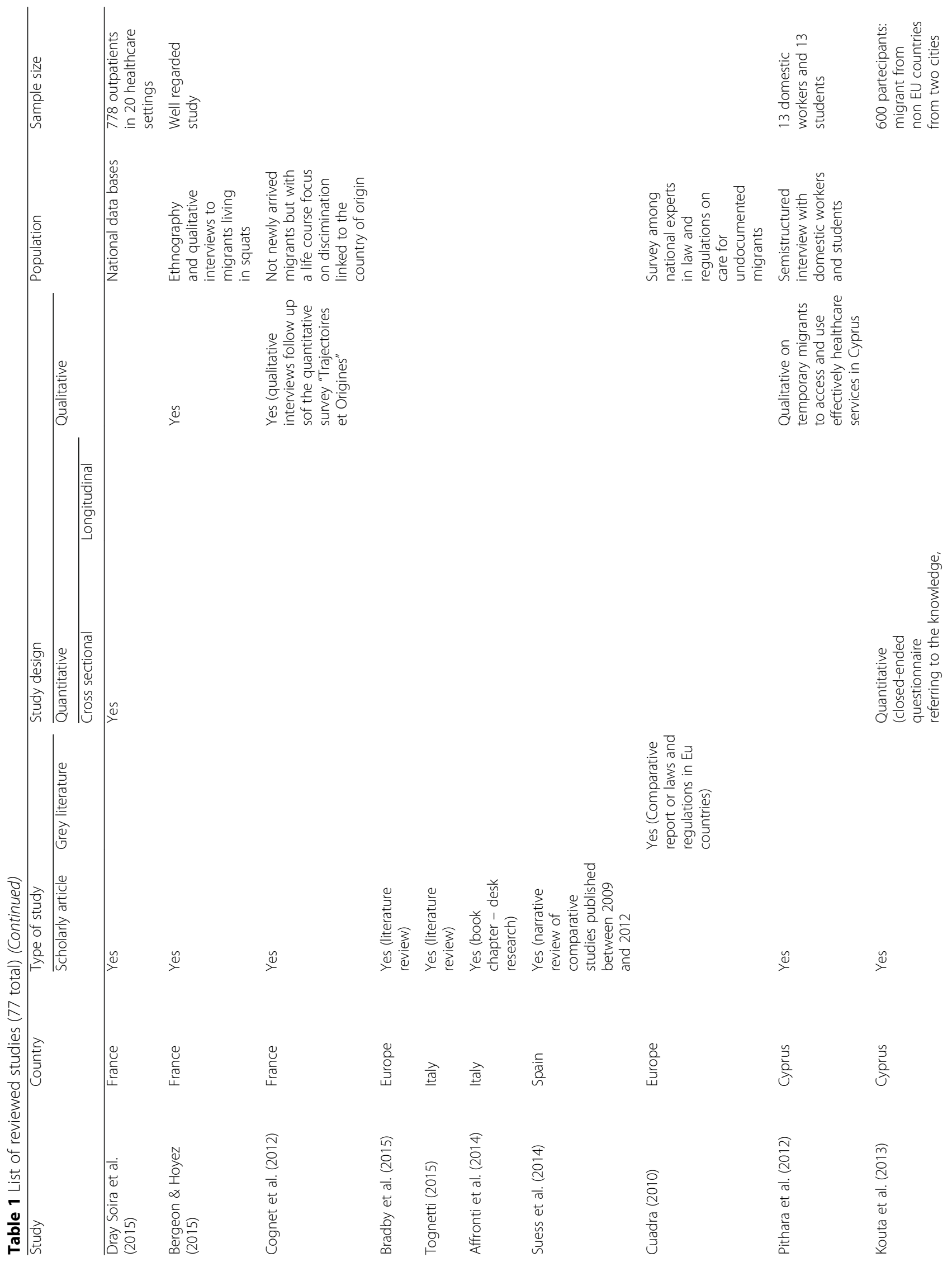




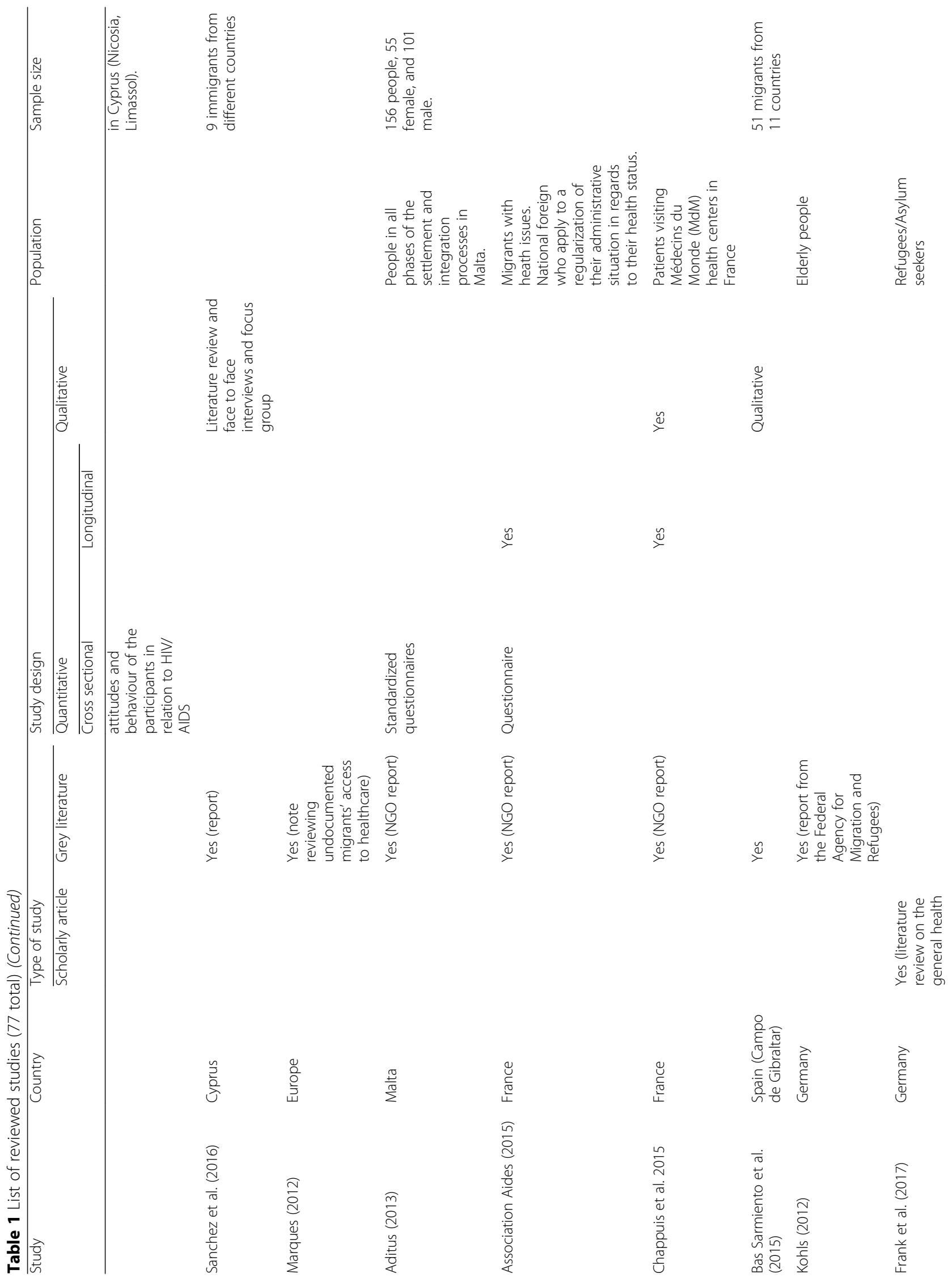




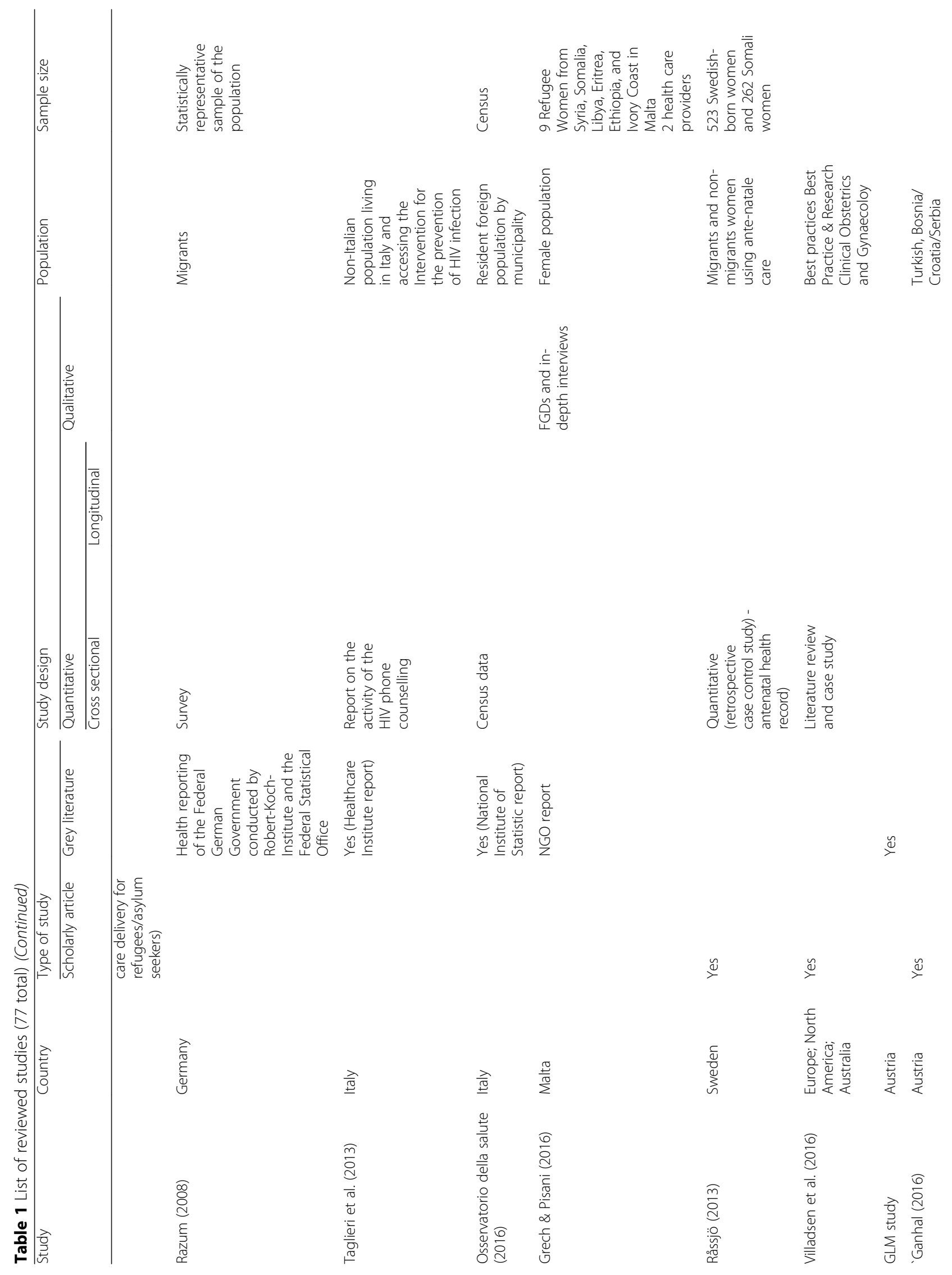




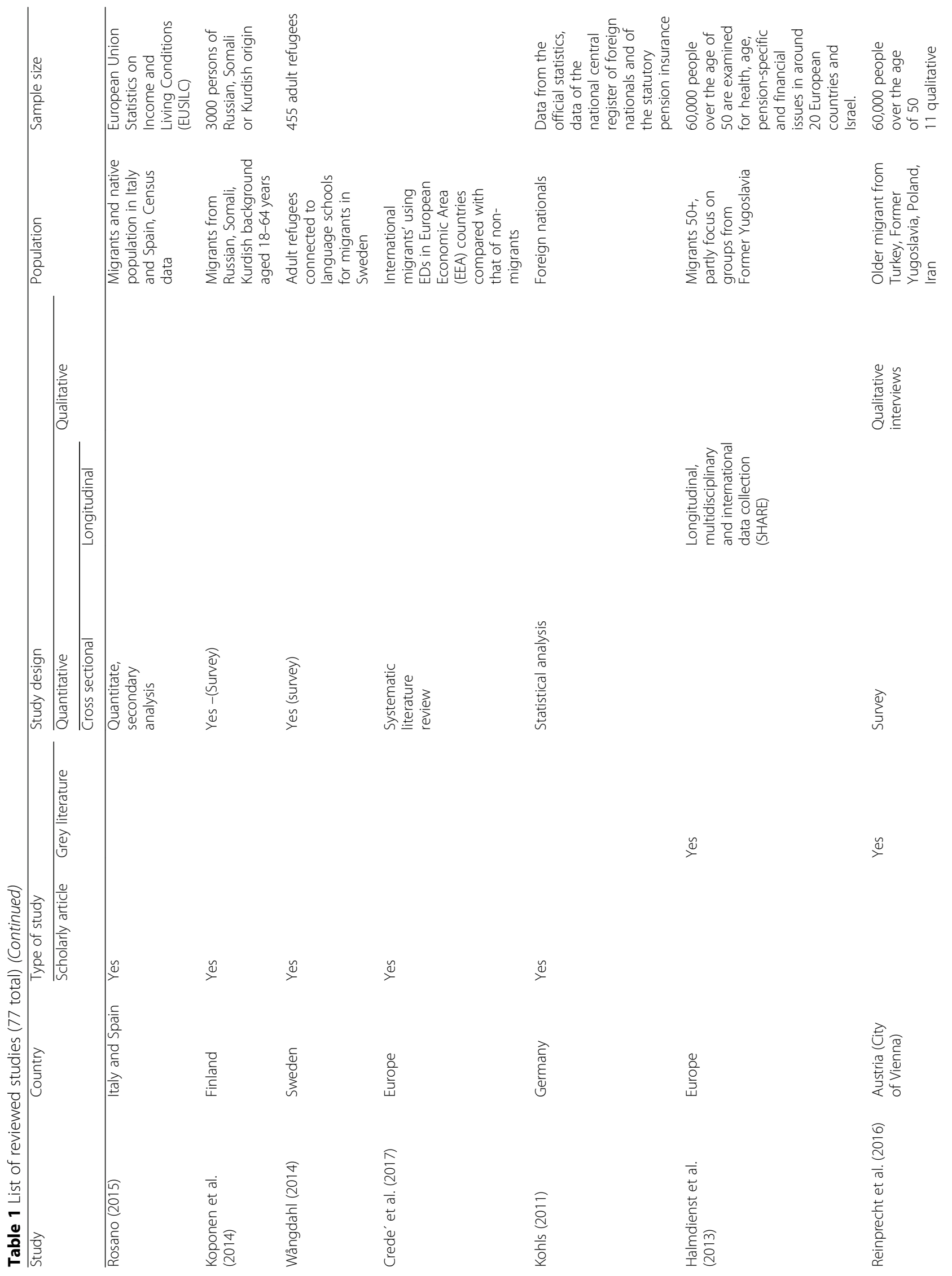




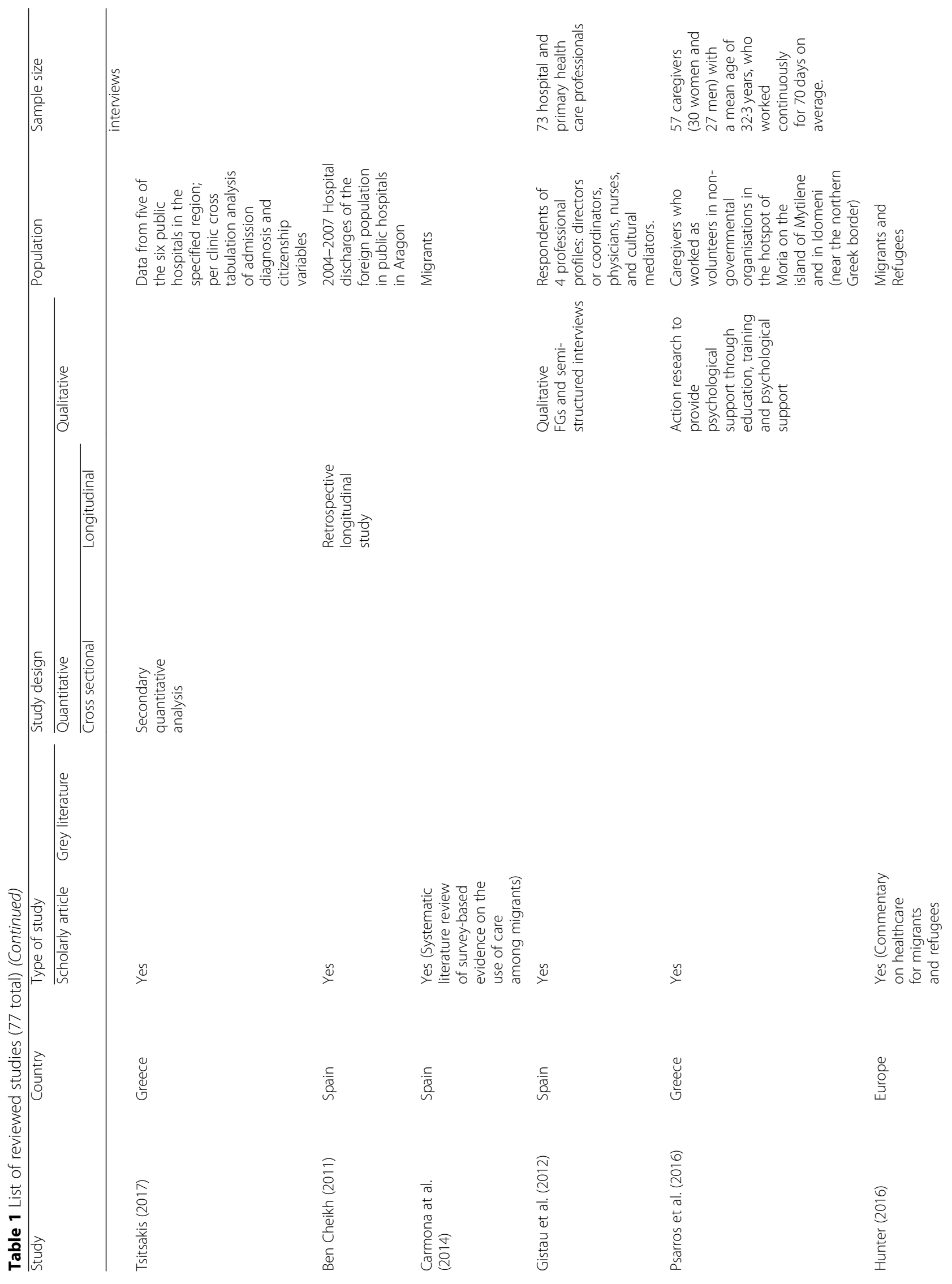




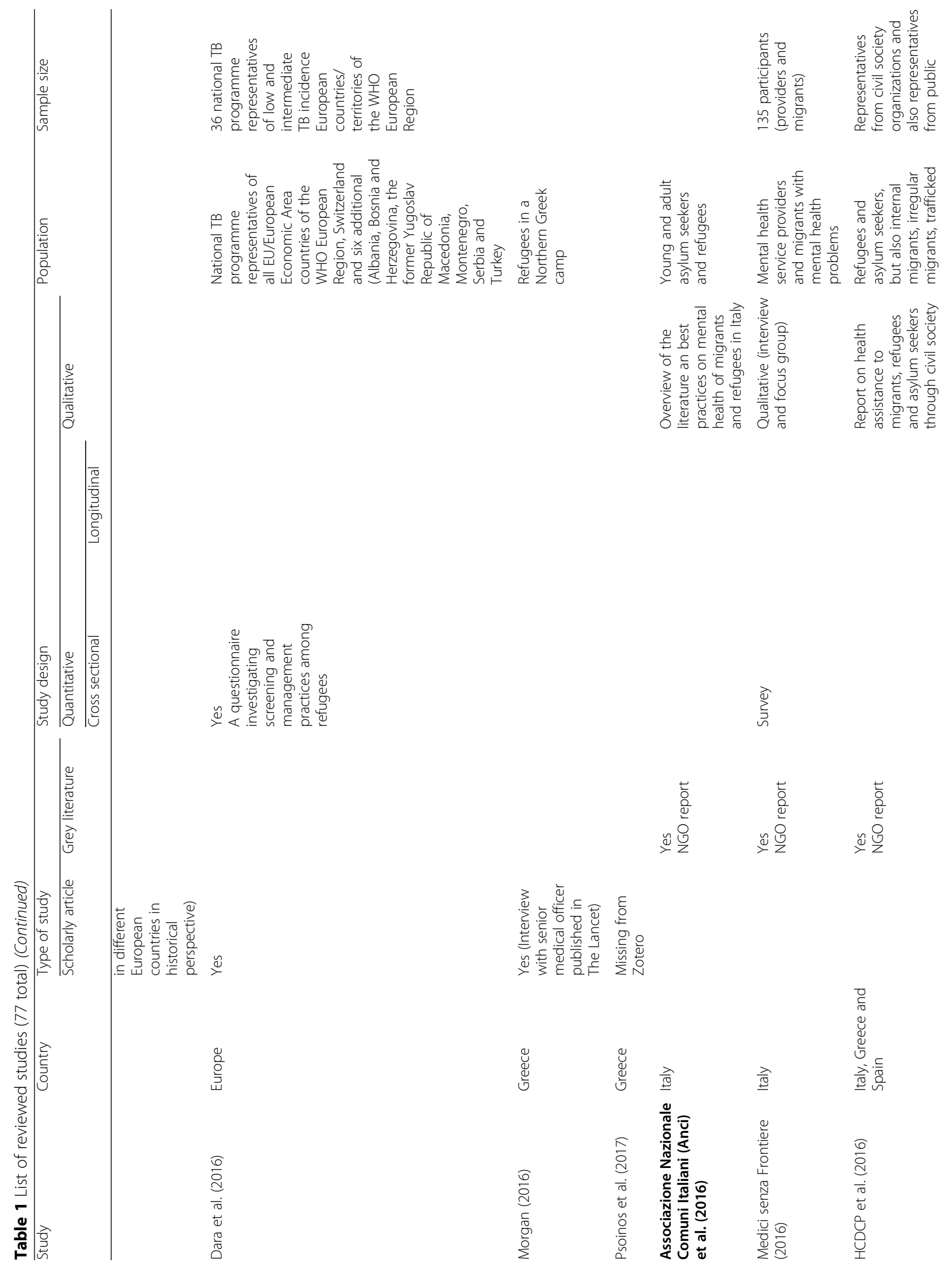




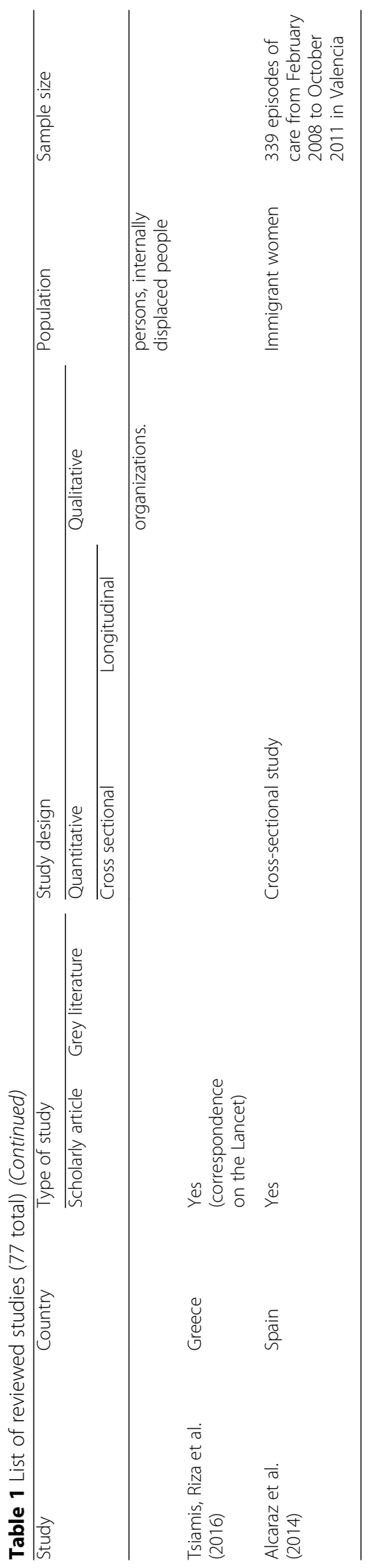




\section{Abbreviations}

EU: European Union; FGC: Female Genital Circumcision; JRS: Jesuit Refugee Service; HIV/AIDS: Human Immunodeficiency Virus/Acquired Immunodeficiency Syndrome; LTBI: Latent Tuberculosis Infection; NGO: NonGovernmental Organization; OECD: Organization for Economic Cooperation and Development; PTSD: Post-Traumatic Stress Disorder; UN: United Nations; WHO: World Health Organization

\section{Acknowledgements}

Our gratitude goes to the members of MigHealthCare Team, without whom this literature review could not have been written. Thank you to Sharon Kassahun, William Grech, Jean-Baptiste Combes, Barbara Bitchnau, Iva Christova, David Brinkmann, Irini Anastassiou, Sara Albiani, Paolo Pezzati.

\section{Authors' contributions}

AL and SH wrote the research article, HB oversighted the writing process providing scientific supervision and approved the final product; the other participants of the MigHealthCare consortium hereby listed - AGS, EDF, JGF, FA, ER, PK, DZ, AL — reviewed evidence in their native language, approved the sections reporting on the national results, and the discussion and conclusions. All authors read, commented and approved the final manuscript.

\section{Funding}

This document is an output of MigHealthCare, a research project partially funded by the European Commission: Consumers, Health, Agriculture and Food Executive Agency. According to the Grant Agreement no 738186. The funding body had no role in carrying out the study. Open access funding provided by Uppsala University.

\section{Availability of data and materials}

The data and material in the form of articles and reports are stored in a Zotero Group that belongs to the MigHealthcare Consortium and will not be shared. The Zotero Group is private to members of the MigHealthcare consortium. Access can only be provided if the leader of the project consents. A request for permission to access can be sent to the leader of the project: Pania Karnaki (p.karnaki@prolepsis.gr), Prolepsis, Institute of Preventive Medicine Environmental \& Occupational Health 7, Fragoklisias street, 151 25, Marousi, Greece.

\section{Ethics approval and consent to participate}

\section{Not Applicable.}

This literature review does not contain any studies with human participants or animals performed by any of the authors. The data analysed was secondary data contained in grey literature and scholarly journal articles.

\section{Consent for publication}

Not Applicable.

\section{Competing interests}

The authors declare that they have no competing interests.

\section{Author details}

${ }^{1} U$ ppsala University, Department of Sociology, English Park Campus - Centre for the humanities, Thunbergsvägen. $3 \mathrm{H}$, Uppsala, Sweden. ${ }^{2}$ University of Edinburgh, School of Social and Political Science, Chrystal Macmillan Building15a, George Square, Edinburgh EH8 9LD, UK. ${ }^{3}$ Polibienestar Research Institute, University of Valencia, Carrer del Serpis, 29, 46022 València, Spain. ${ }^{4}$ Arènes and ICM fellow, Rennes, France. ${ }^{5}$ Department of Hygiene, Epidemiology and Medical Statistics Medical School, National and Kapodistrian University of Athens, 75 Mikras Asias, Goudi, 11527 Athens, Greece. ${ }^{6}$ Prolepsis, Institute of Preventive Medicine Environmental \& Occupational Health 7, Fragoklisias street, 15125 Marousi, Greece.

\section{Received: 7 June 2019 Accepted: 22 April 2020}

\section{Published online: 30 June 2020}

\section{References}

1. United Nations. Migration. 2018. Available from: https://www.un.org/en/ sections/issues-depth/migration/index.html. Cited 2019 May 31.
2. Eurostat. Migration and migrant population statistics - Statistics Explained. 2015. Available from: http://ec.europa.eu/eurostat/statistics-explained/index. php/Migration_and_migrant_population_statistics. Cited 2018 Feb 2.

3. Rechel B. Migration and health in European Union. Maidenhead: McGraw Hill/Open University Press; 2011. p. 257. European Observatory on Health Systems and Policies series.

4. Matlin SA, Depoux A, Schütte S, Flahault A, Saso L. Migrants' and refugees' health: towards an agenda of solutions. Public Health Rev. 2018;39(1):27.

5. Peters M, Godfrey C, Khalil H, McInerney P, Parker D, Soares CB. Guidance for conducting systematic scoping reviews. Int J Evid Based Healthc. 2015: 13(3):141-6.

6. Berchet $\mathrm{C}$, Jusot $\mathrm{F}$. État de santé et recours aux soins des immigrés en France : une revue de la littérature. Numéro Thématique Santé Recours Aux Soins Migr En Fr. 2012;17(2-3-4):17-21.

7. Estrada J, Lazimi G. Vulnérabilité des femmes migrantes en situation de précarité face aux violences en France. Cah SANTE PUBLIQUE Prot Soc. 2013:29-34.

8. Rechel B, Mladovsky P, Devillé W. Monitoring migrant health in Europe: a narrative review of data collection practices. Health Policy. 2012;105(1):10-6.

9. Rommel A, Saß AC, Born S, Ellert U. Die gesundheitliche Lage von Menschen mit Migrationshintergrund und die Bedeutung des sozio?konomischen Status: Erste Ergebnisse der Studie zur Gesundheit Erwachsener in Deutschland (DEGS1). Bundesgesundheitsbl Gesundheitsforsch Gesundheitsschutz. 2015;58(6):543-52.

10. Kotsioni I, Egidi S, Ponthieu A. Health at risk in immigration detention facilities. Deten Altern Deten Deport. 2013;44:11-3.

11. D'Hermies F, de Champs-Léger H. Article original: Ophtalmologie et situation de précarité en milieu urbain. À propos d'une expérience de 150 patients. J Fr Ophtalmol. 2015;38(1):1

12. D'Hermies F, de Champs-Léger H. Ophthalmology and urban underprivileged. Experience of 150 patients. J Fr Ophtalmol. 2015;38(1):1-6.

13. Lot F, Saura C, Semaille C, Cazein F, Che D, Larsen C, et al. Trois pathologies infectieuses fréquemment rencontrées chez les migrants en France : le VIH, la tuberculose et l'hépatite B. Numéro Thématique Santé Recours Aux Soins Migr En Fr. 2012;17(2-3-4):25-30.

14. Che D, Antoine D. Epidemiology of tuberculosis in France in 2008. Med Mal Infect. 2011;41(7):372-8.

15. Albares MP, Belinchón I, Ramos JM, Sánchez-Payá J, Betlloch I. Epidemiologic study of skin diseases among immigrants in Alicante. Spain. Actas Dermosifiliogr. 2012;103(3):214-22.

16. Aguilar-Duran S, Sánchez MF. Epidemiological analysis of tuberculous lymphadenopathy in a district of Barcelona: proposal of a diagnostic algorithm. Rev Esp Salud Publica. 2014;88(3):339-48.

17. Calderón Sandubete E, Yang Lai R, Calero Bernal ML, Martínez Rísquez MT, Calderón Baturone M, de la Horra Padilla C. Chronic viral hepatitis B and C in immigrant population. Spain. Rev Esp Salud Publica. 2014;88(6):811-8.

18. Simonnot N, Rodriguez A, Nuenberg M, Fille F, Aranda-Fernandez P-E, Chauvin P. Access to healthcare for people facing multiple vulnerabilities in health in 31 cities in 12 countries; 2016.

19. ANCI, CARITAS ITALIANA CITTALIA FONDAZIONE MIGRANTES SERVIZIO CENTRALE DELLO SPRA. Rapporto sulla protezione internazionale in Italia 2016. 2016. Available from: http://viedifuga.org/wp-content/uploads/2 016/11/report-on-international-protection-in-Italy-2016 light.pdf.

20. Taylor-East R, Rossi A, Caruana J, Grech A, et al. BJPsych Int. 2014;13(2):32-5.

21. Camilleri N, Taylor R. Socio-economic status and population density risk factors for psychosis: prospective incidence study in the Maltese islands. Int Psychiatry. 2010;7(3):69-71.

22. Monpierre $\mathrm{O}$, Baudino $\mathrm{P}$, Rio-René $\mathrm{P}$, Maurice S, Malvy D, Receveur M-C. État de santé des mineurs isolés étrangers accueillis en Gironde entre 2011 et 2013. (French). Bull Soc Pathol Exot. 2016;109(2):99.

23. Pavlopoulou I, Tanaka M, Dikalioti S, Samoli E, Nisianakis P, Boleti O, et al. Clinical and laboratory evaluation of new immigrant and refugee children arriving in Greece. BMC Pediatr. 2017;17(1):132.

24. Giannakopoulos G, Anagnostopoulos D. Child health, the refugees crisis, and economic recession in Greece. Lancet. 2016;387(10025):1271.

25. Bodenwinkler A, Kerschbaum J, Sax G. Länder-Zahnstatuserhebung 2012 Zwölfjährige in Österreich Zwölfjährige Kinder mit und ohne Migrationshintergrund. Available from: http://www.hauptverband.at/ cdscontent/load?contentid=10008.597921. Cited 2017 Jul 26.

26. Kaoutar B, Gatin B, de Champs-Leger H, Vasseur V, Aparicio C, de Gennes C, et al. Socio-demographic characteristics and health status of patients at a 
free-of-charge outpatient clinic in Paris. Rev Med Interne. 2014;35(11):70914.

27. Kaoutar B, Mathieu-Zahzam L, Lebas J, Chauvin P. Health of immigrant population of consultants at the Baudelaire outpatient clinic in SaintAntoine hospital in Paris, France. Bull Soc Pathol Exot 1990. 2012;105(2):86.

28. Debono M, Grazia C. Labour market integration of asylum seekers and refugees. Malta: European Commission; 2016. Available at: https:/www.um. edu.mt/library/oar/bitstream/123456789/21899/1/Malta-AHR_ LMIntegrationOfAsylumSeekers_RefugeesMay2016_Final.pdf.

29. Barda L, Chappuis M, Godard N. Les conditions d'hébergement des personnes en situation de grande précarité. Une enquête auprès des patients rencontrés par médecins du monde en île-de-France. Paris: MDM; 2016. p. 27.

30. Dray Spira R, Gigonzac V, Vignier N, Pannetier J, Sogni P, Lert F, et al. Caractéristiques des personnes originaires d'Afrique subsaharienne suivies pour une hépatite B chronique en Île-de-France en 2012-2013. Données de I'enquête ANRS-Parcours. Numéro Thématique Hépat B C Delta En Fr Dépist A Encourag. 2015;19-20:339-47.

31. Bergeon C, Hoyez A-C. Etre migrant et vivre en squat. 2015; Available from: http://search.ebscohost.com/login.aspx?direct=true\&site=eds-live\&db= edsrev\&AN=edsrev.9EBD3559. Cited 2017 Jun 6.

32. Cognet M, Hamel C, Moisy M. Santé des migrants en France : l'effet des discriminations liées à l'origine et au sexe. 2012; Available from: http:// search.ebscohost.com/login.aspx?direct=true\&site=eds-live\&db=edsrev\&AN= edsrev.AE83E39F. Cited 2017 Jun 6.

33. Bradby $H$, Humphris $R$, Newall D, Phillimore J, Health Evidence Network, World Health Organization, et al. Public health aspects of migrant health: a review of the evidence on health status for refugees and asylum seekers in the European region. 2015. Available from: http://www.euro.who.int/_data/ assets/pdf_file/0004/289246/WHO-HEN-Report-A5-2-Refugees_FINAL. pdf?ua=1. Cited 2017 May 4.

34. Tognetti M. Health inequalities; 2015. https://doi.org/10.4236/jss.2015.34002.

35. Mario Affronti, Giovanni Baglio, Salvatore Geraci, Maurizio Marceca, Maria Laura Russo. Responsabilità ed equità per la salute dei migranti: un impegno da condividere. 2014. Available from: https://docs.google.com/ document/d/1vbgTHMw6YTdZ2GuDfrpgpYk3mWonPNUwPbpMDRiyhE/ edit.

36. Suess A, Ruiz Perez I, Ruiz Azarola A, March Cerda JC. The right of access to health care for undocumented migrants: a revision of comparative analysis in the European context. Eur J Pub Health. 2014;24(5):712-20.

37. Bjorngren CC. Policies on health care for undocumented migrants in EU 27. MIM/Health and Society, Malmo University; 2010.

38. Pithara C, Zembylas M, Theodorou M. Access and effective use of healthcare services by temporary migrants in Cyprus. Int J Migr Health Soc Care. 2012; 8(2):72-85.

39. Kouta C, Phellas C, Charis K. Knowledge, attitudes and perceptions of immigrants from third countries in Cyprus, on HIV/AIDS and sexual and reproductive health. The implication of nursing ethics to healthcare. Health Sci J. 2013;7(3):258-68.

40. Marques TVGA. Refugees and migrants struggle to obtain health care in Europe. Can Med Assoc. 2012;184(10):E531-2.

41. Aditus U. Nitkellmu? Refugee Integration Perspectives in Malta. Malta: aditus (NGO); UNHCR; 2013. p. 33. Available from: http://www.unhcr.org.mt/newsand-views/press-releases/732-nitkellmu-perspectives-on-refugee-integrationin-malta.

42. Chappuis M, Romasino A, Didier E, Gaboret C, Mari C, Mathieu C, et al. Observatoire de l'accès aux soins de la mission France de Médecins du Monde. Rapport. 2015;2015:69.

43. Bas-Sarmiento P, Fernández-Gutiérrez M, Albar-Marín MAJ, García-Ramírez M. Perceptions and experiences of access to health services and their utilization among the immigrant population. Gac Sanit. 2015;29(4):244-51.

44. Frank L, Yesil-Jürgens R, Razum O, Bozorgmehr K, Schenk L, Gilsdorf A, et al. Gesundheit und gesundheitliche Versorgung von Asylsuchenden und Flüchtlingen in Deutschland: RKI-Bib1 (Robert Koch-Institut); 2017.

45. Razum O, Neuhauser H, Robert-Koch-Institut. Migration und Gesundheit. Berlin: Robert-Koch-Inst; 2008. p. 135. (Schwerpunktbericht der Gesundheitsberichterstattung des Bundes).

46. Taglieri FM, Colucci A, Barbina D, Fanales-Belasio E, Luzi AM Communication and cultural interaction in health promotion strategies to migrant populations in Italy: the cross-cultural phone counselling experience. Ann Ist Super Sanita. 2013;49(2):138-42.
47. Osservatorio sulla salute. RAPPORTO OSSERVASALUTE - Stato di salute e qualità dell'assistenza nelle Regioni Italiane 2015: Osservatorio sulla Salute: 2016. p. 59. Available from: http://www.osservatoriosullasalute.it/wpcontent/uploads/2016/09/ro-2015-arg-15_salute_della_popolazione_ straniera.pdf.

48. Råssjö EB, Byrskog U, Samir R, Klingberg-Allvin M. Somali women's use of maternity health services and the outcome of their pregnancies: a descriptive study comparing Somali immigrants with native-born Swedish women. Sex Reprod Healthc Off J Swed Assoc Midwives. 2013;4(3):99-106.

49. Villadsen SF, Mortensen LH, Andersen A-MN. Care during pregnancy and childbirth for migrant women: how do we advance? Development of intervention studies - the case of the MAMAACT intervention in Denmark. Best Pract Res Clin Obstet Gynaecol. 2016;32:100-12.

50. Ganahl. Gesundheitskompetenz bei Personen mit Migrationshintergrund aus der Türkei und Ex-Jugoslawien in Österreich. Ergebnisse einer quantitativen und qualitativen Studie. 2016. LBIHPR Forschungsbericht. (PDF Download Available). ResearchGate. Available from: https://www. researchgate.net/publication/307850011_Gesundheitskompetenz_bei_ Personen_mit_Migrationshintergrund_aus_der_Turkei_und_Ex-Jugoslawien_ in_Osterreich_Ergebnisse_einer_quantitativen_und_qualitativen_Studie_ LBIHPR_Forschungsbericht.

51. Rosano A. 6. WC poster walk: migrant and ethnic minority health. Eur J Pub Health. 2015;25:3.

52. Koponen P, Kuusio H, Keskimäki I, Mölsä M, Manderbacka K, Castaneda A, et al. Unmet needs for medical care among migrants in FinlandPäivikki Koponen. Eur J Pub Health. 2014;24(suppl_2).

53. Wangdahl J, Lytsy P, Martensson L, Westerling R. Health literacy among refugees in Sweden-a cross-sectional study. BMC Public Health. 2014;14(1): 1030.

54. Credé SH, Such E, Mason S. International migrants' use of emergency departments in Europe compared with non-migrants' use: a systematic review. Eur J Pub Health. 2017;16.

55. Kohls M. Morbidität und Mortalität von Migranten in Deutschland. 1. Aufl. Nürnberg: Bundesamt für Migration und Flüchtlinge; 2011. p. 282. (Forschungsbericht / Bundesamt für Migration und Flüchtlinge).

56. Halmdienst N, Radhuber M, Winter-Ebmer R. GEKOMMEN UM ZU BLEIBEN: Konturen von alternden Migrantinnen und Migranten in Österreich Eine Untersuchung der allgemeinen Lebens- und gesundheitlichen Situation von Migrantinnen und Migranten im Alter 50+. 2013. Available from: https:// www.sozialministerium.at/cms/site/attachments/6/9/7/CH3434/CMS145 9846187382/08_konturen_von_alternden_migrantinnen.pdf. Cited 2017 Jul 28.

57. Tsitsakis C, Karasavvoglou A, Tsaridis E, Ramantani G, Florou G, Polychronidou $P$, et al. Features of public healthcare services provided to migrant patients in the eastern Macedonia and Thrace region (Greece). Health Policy. 2017;121(3):329-37.

58. Ben Cheikh W, Abad JM, Arribas F, Andrés E, Rabanaque MJ. por el Grupo de Investigación en Servicios Sanitarios (GRISSA). Public hospital utilization by the foreign population in Aragon, Spain (2004-2007). Gac Sanit. 2011: 25(4):314-21.

59. Carmona R, Alcázar-Alcázar R, Sarria-Santamera A, Regidor E. Use of health services for immigrants and native population: a systematic review. Rev Esp Salud Publica. 2014;88(1):135-55.

60. Llosada Gistau J, Vallverdú Duch I, Miró Orpinell M, Pijem Serra C, Guarga RA. The access to health services and their use by immigrant patients: the voice of the professionals. Aten Primaria. 2012;44(2):82-8.

61. Psarros C, Malliori M, Theleritis C, Martinaki S, Bergiannaki J. Psychological support for caregivers of refugees in Greece. Lancet. 2016;388(10040):130.

62. Hunter $P$. The refugee crisis challenges national health care systems: countries accepting large numbers of refugees are struggling to meet their health care needs, which range from infectious to chronic diseases to mental illnesses. EMBO Rep. 2016;17(4):492-5.

63. Dara M, Solovic I, Sotgiu G, D'Ambrosio L, Centis R, Tran R, et al. Tuberculosis care among refugees arriving in Europe: a ERS/WHO Europe region survey of current practices. Eur Respir J. 2016;48(3):808-17.

64. Morgan J. Frontline: providing health care in Greece's refugee camps. Lancet. 2016;388(10046):748.

65. MSF (Medici Senza Frontiere). Traumi ignorati. 2016.

66. Hcdcp, Praksis, PROOPTIKI, CMT, MINSALUTE, AOUMEYER, et al. State of the art on Public Health aspects of the "people on the move" in Greece, Italy and Slovenia. 2016. 
67. Tsiamis C, Terzidis A, Kakalou E, Riza E, Rosenberg T. Is it time for a refugees' health unit in Greece? Lancet. 2016;388(10048):958.

68. Alcaraz Quevedo M, Paredes-Carbonell JJ, Sancho Mestre C, López-Sánchez P, García Moreno JL, Vivas CD. Immigrant women care in a health intercultural mediation program. Rev Esp Salud Publica. 2014;88(2):301-10.

69. Biffl G. Socio-Economic Determinants of Health and Identification of Vulnerable Groups in the Context of Migration. The Case of Austria (PDF Download Available). ResearchGate. 2015. Available from: https://www. researchgate.net/publication/23729296_Socio-Economic_Determinants_of_ Health_and_Identification_of_Vulnerable_Groups_in_the_Context_of_ Migration_The_Case_of_Austria.

70. Valeska Padovese AME, Tanya Melillo Fenech MPC, Daniele Didero GC, Mirisola C. Migration and determinants of health: clinical epidemiological characteristics of migrants in Malta (2010-11). J Public Health. 2014;36(3): 368-74.

71. Castro VA, et al. Med Clin (Barc). 2013;140(9):424-5.

72. MSc candidate London School of Hygiene and Tropical Medicine. HIV and the Sub-Saharan African Migrant Community in Malta: A Study Assessing Prevalence, Knowledge and Attitudes Towards Testing; London School of Hygiene and Tropical Medicine, Sept 2012, vol. 2012. Malta/London: London School of Hygiene and Tropical Medicine; 2011. p. 49.

73. Aichberger M, Rapp MA. Migranten im Alter. In: Praxis der Interkulturellen Psychiatrie und Psychotherapie: Elsevier; 2011. p. 271-6. Available from: http://linkinghub.elsevier.com/retrieve/pii/B9783437245701100285. Cited $2017 \mathrm{Jul} 3$.

74. Crepet A, Rita F, Reid A, den Boogaard WV, Deiana P, Quaranta G, et al. Mental health and trauma in asylum seekers landing in Sicily in 2015: a descriptive study of neglected invisible wounds. Confl Heal. 2017;11(1):1.

75. Bourbotte L, Meritet JF, Lebon P, Gendrel D. Service de pédiatrie. Université Paris Descartes. Hôpital Saint Vincent de Paul-Cochin. Paris. FRA, =Service de virologie. Université Paris Descartes. Hôpital Saint Vincent de Paul-Cochin. Paris. FRA. Séroprévalence de l'hépatite A chez les enfants issus de familles immigrées vivant en France et conséquences pour la vaccination. Arch Pediatr. 2011;18(6):643-5.

76. Dr Maria Pisani MG, Daniela Grech ET. My Diversity: Age, Gender and Diversity Perspectives in the Maltese Refugee Context. Malta: Integral Foundation and UNHCR; 2015. p. 84. Available from: http://www.unhcr.org. $\mathrm{mt} /$ news-and-views/press-releases/823-my-diversity.

77. Kohls M. Sterberisiken von Migranten: Analysen zum Healthy-Migrant-Effekt nach dem Zensus 2011. Bundesgesundheitsbl Gesundheitsforsch Gesundheitsschutz. 2015;58(6):519-26.

78. Reinprecht C, Rossbacher E, Wilczewska I, Alpagu F, Koyupinar D. Einfluss der Migration auf Leistungserbringung und Inanspruchnahme von Pflegeund Betreuungsleistungen in Wien. Available from: https:/www.wien.gv.at/ gesundheit/einrichtungen/planung/pdf/migration.pdf. Cited 2017 Jul 24.

79. Farka L. Analysis and comparative review of equality data collection practices in the European Union. Data collection in the field of ethnicity: EUROPEAN COMMISSION Directorate-General for Justice and Consumers Directorate D - Equality Unit JUST/D1; 2017.

80. O'Donnell CA, Burns N, Mair FS, Dowrick C, Clissmann C, van den Muijsenbergh $\mathrm{M}$, et al. Reducing the health care burden for marginalised migrants: the potential role for primary care in Europe. Health Policy. 2016; 120(5):495-508.

\section{Publisher's Note}

Springer Nature remains neutral with regard to jurisdictional claims in published maps and institutional affiliations.

Ready to submit your research? Choose BMC and benefit from:
- fast, convenient online submission
- thorough peer review by experienced researchers in your field
- rapid publication on acceptance
- support for research data, including large and complex data types
- gold Open Access which fosters wider collaboration and increased citations
- maximum visibility for your research: over 100M website views per year
At BMC, research is always in progress.
Learn more biomedcentral.com/submissions

